\title{
Real World, Microscopic World and Language
}

\author{
Davide Schiffer* \\ Research Center, Policlinico di Monza, Vercelli, Italy
}

Received: February 16, 2017; Accepted: March 01, 2017; Published: March 20, 2017

*Corresponding author: Davide Schiffer, Research Center, Policlinico di Monza, Vercelli, Italy, E-mail: davide.schiffer@unito.it

\begin{abstract}
The recognition of an object in the microscopic field occurs through a Gestaltic pathway, requires a denomination of it, and is regulated by the relationship sign/receptor. The reality is modified by the technical procedures for its demonstration and changes at every magnification. Everything is regulated according to the anthropic principle and anthropocentrism. The interpretation is given according to the personal living experience and prejudice and the recognition of the object is accomplished through the language in a nominalistic way on the basis of the knowledge that the external world is internalized through linguistic categories. To know means to modify oneself and the world and it is realized through an internal signaling system that needs to be validated by the inter-subjectivity; it can be influenced by criticism failures and unconscious mechanisms, as in the psychiatric delusion or in ideologies.

*This article develops some themes contained in the book "Through the microscope. "Neuroscience and bases of clinical reasoning" (in Italian), published by Springer, Milan, 2011.
\end{abstract}

\section{Introduction}

The microscope is a totally useless tool without two eyes fixed on the eyepieces and a mind behind it investigating, recognizing and denominating things. Apart from the need to manipulate the substrate in order to make it suitable for studying, a variety of mechanisms intervene between observation and the conclusions involving brain and mind. Besides the relativism of drawn conclusions, there exists the possibility that the interference of neuro-psychic events may induce wrong conclusions. This paper is the result of the personal experience of researchers using the microscope to discriminate the external world.

\section{Material and methods}

The material is whatever substrate of the external world whose structure one wishes to study and/or recognize. The method is that of observation, common to everyone using this tool.

\section{Results and discussion}

Observation under the microscope makes you feel you're entering a world on its own with no relationship with the external world from which it is mandatory to withdraw in order to stay focused. To observe at the microscope also means entering a two- dimensional vision of a three-dimensional reality that therefore needs to be corrected. Moreover, you know that the reality you are observing has been manipulated in order to become observable. Using different magnifications, you see different realities and it is difficult to say which the true one is. Before the observation you have to decide what you want, or don't want, to find out. Looking at reality with the naked eye, it can be said that the brain is in the skull, the hippocampus is in the brain and it has a certain form and color, but I cannot go deeper. I do not know the magnitude relationships between eyes, brain and mind or how it is for animals, but I know that they must be typical to species, probably on the basis of the meaning they have for each of the species. For example, will an object inspiring fear or representing food be seen as larger in order to grab attention? Semiotics teaches us that for every sign in nature there is a corresponding receptor in the living being, so that its reading derives from this complementarity. Also in humans, the forms and magnitudes of the external world are relevant to the structures that detect them, according to a material logic.

By experience, I know that the objects under an optical microscope are composed by progressively smaller structures that I am able to see only by using progressively higher magnifications and manipulations. I can see that the hippocampus contains neurons and, in turn, these are composed of organelles still composed of smaller structures visible with the electron microscope and going deeper, we enter into chemistry and then physics. At every magnification the context changes and the same is true for my reading apparatus, because, I must activate the quantity of knowledge appropriate to the context [1]. In general, it is known that the forms and magnitudes of the external world are not only read by the relevant receptors, but can also induce them.

I cannot say that the external world exists only if I look at it, because as a scientist I must comply with the objectivity of nature, but I know that it can be perceived through other means than eyesight, even immaterial means such as electromagnetic waves and I can also have a mere mental image of it. The evaluation of objects in the microscopic field is not only a visual question, but also one of space management involving proprioceptive stimuli.

We cannot avoid an anthropocentric bias in our microscopic observation, because animals capture the external world according to their phylogenetic position. We must accept that it 
exists independently of our visual apparatus and consciousness Scientifically, we must behave as if nature were objective, as in the "functional fiction" [2].

When I put a piece of tissue under the microscope after appropriate manipulations and at a given magnification I can see cells. But are they really cells? Do they have a tag on them that says "we are cells"? They don't, I am the one attributing a name to a certain reality. By saying they are cells, I recognize them and call them "cells" because I interpret such reality on the basis of my scientific lived experience and the name I give them will ever interpose between myself and them. If I increase magnification, I will see other structures that I will call mitochondria, vacuoles and so on, and using Polymerase Chain Reaction I will see other things such as colored bands that I will call proteins or nucleotides on the basis of what has been approved by scientific inter-subjectivity. This means that the recognition of the external world will occur through the intervention of my mind that will denominate it - I will use language. If it were an animal instead of me, would the recognition of the external world take place through the reading and interpretation of the signs it sees and with the receptors it possesses, without the need to denominate them?

When I was attending grammar school I became infatuated with systematic botanics, with Linnaeus and his saying "nomina si nescis perit et cognitio rerum" (if you don't know the names, the knowledge of things perishes also) going back to the question of the "universals" and to the nominalism of William of Ockham, Abelard and Duns Scotus. Later the problem became a key issue in semiotics, the discipline that studies signification and communication phenomena, based on "something that stands for something else". Famous scholars in this discipline include and others who debated whether it belonged to philosophy, linguistics or philology [1,3-8]. In association with cognitive neuropsychology, it entered neurology placing the emphasis on the language, the knowledge and biology of semiotic-cognitive functions, inseparably from neo-Darwinism and Neurosciences in general [9-11].

Someone once said that knowing means to change the world and oneself, but in the process of knowing we can only reach the features of things and not their soul, through reading, understanding and interpreting the signs [12]. The signs are internalized and an internal signaling system is established representing the patterns for recognition of the objects of the external world. Our knowledge is based on the exploration of signs and significance; it is always subjective, but it becomes objectified through standardization and in this way codes are formed. In the process of knowledge, a historicization takes

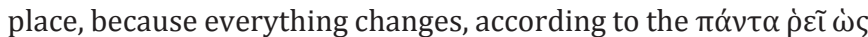

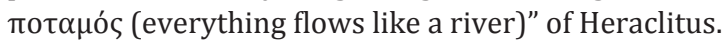

The analogical internal system of signaling mentioned above does not correspond to the external signs and it does not reproduce the facts, because it has been built by interpretations and elaborations and integrated into the lived experience through instincts, feelings and other perceptions and then confronted with the reality objects. Language is a great intermediary and it would develop from inter-subjectivity, according to the natural logic; verbal communication would be an organized system of a sign function and a linguistic communication. Knowledge would be an inter-subjective and linguistic exploration. To find a name would be to use the analogical function as the basis for categorization. The logical operations would always be categorical identifications.

\section{Conclusions}

In discussing this matter, in which renowned scientists were involved, it must be emphasized that language and interpretations will always interpose between myself and the real world $[1,3,13,14]$. According to Wittgenstein, the logical form would be common to language and facts, so that to be in the world or to think the world would be the same thing [15]. This is also Heidegger's thought. The external world would be assumed according to linguistic categories to the point that a linguistic determinism could exist [16].

The issue of the perception of space under the microscope must be seen as an integration between vision and kinesthesia [17].

\section{References}

1. Eco U. A theory of semiotics. Indiana University Press. Bloomington. 1978;378.

2. Vaihinger H. The Philosophy of 'As if'. Barnes and Noble. New York. 1968.

3. Peirce CS. Peirce on signs: writing on semiotics. University of North Carolina Press. Chapel Hill. 1991;294.

4. Sebeok TA. Signs: an introduction to semiotics. University of Toronto Press, Toronto. 2001.

5. Levi-Strauss C. Structural anthropology. Basic Books. New York. $2008 ; 352$.

6. Lacan J. Ecrits. A selection. Norton \& Co, New York. 1977.

7. Chomsky N. Language and mind. III ed. Cambridge University Press, New Yok. 2006.

8. De Mauro. Lezioni di linguistica teorica, Laterza, Rome-Bari. 2008

9. Searle JR. Mind, language and society: philosophy in the real world. Paperback. 1998.

10. Kandel ER. In search of memory. The emergence of a new science of mind. Norton \& Co, New York. J Clin Invest. 2006;116(5):1131.

11. Edelman G. Neural Darwinism. The Theory of Neuronal Group Selection. Basic Books, New York. 1987.

12. Prodi G. Le basi materiali della significazione. Bompiani, Milano. 1977.

13. De Saussure F. Course in general linguistic. Paperback.1998.

14. Greimas AJ. Structural semantics. An Attempt at a method. University of Nebraska Press. Lincoln. 1983.

15. Wittgenstein L. Tractatus logico-philosophicus. Routledge, LondonNew York. 2001.

16. Whorf B. Language thought and reality, Selected writings of Benjamin Lee Technology Press of Massachusetts Institute of Technology. Cambridge, Mass. 1997.

17.Gibson James J. The Senses considered as perceptual systems. Greenwood Press, Westport, 1966. 